Note

\title{
MICROSPOROGENESIS IN BRACHIARIA BOVONEI (CHIOV.) ROBYNS AND B. SUBULIFOLIA (MEZ) CLAYTON (POACEAE)
}

\author{
Claudicéia Risso-Pascottoํㅜ ; Maria Suely Pagliarini ${ }^{1 *}$; Cacilda Borges do Valle ${ }^{2}$ \\ ${ }^{1}$ Depto. de Biologia Celular e Genética, Av. Colombo, 5.790, 87020-900 - Maringá, PR - Brasil. \\ ${ }^{2}$ Embrapa Gado de Corte, C.P.154 - 79002-970 - Campo Grande, MS - Brasil. \\ *Corresponding author <mspagliarini@uem.br>
}

\begin{abstract}
Some African species of Brachiaria have been introduced into the Americas and became the most important forage for pastures in the tropics. New cultivars can be obtained either from direct selections from the natural existing variability in the germplasm collections or from interspecific hybridizations. Polyploidy is predominant in the genus Brachiaria and correlated with apomixis which complicates hybridization. The objective of cytological studies underway on the Brachiaria germplasm collection at Embrapa Beef Cattle is to determine the chromosome number and meiotic behavior of accessions. For the breeding of Brachiaria species, compatible sexual and apomictic accessions need to be identified. Microsporogenesis was evaluated in two accessions of Brachiaria bovonei (BO01 and BO05) and one accession of B. subulifolia (SU01). BO01 is pentaploid ( $2 \mathrm{n}=5 \mathrm{x}=$ 45), BO05 is tetraploid ( $2 n=4 x=36)$, and SU01 is hexaploid $(2 n=6 x=54)$, derived from $x=9$. Meiotic abnormalities typical of polyploids, characterized by precocious chromosome migration to the poles in metaphases, laggard chromosomes in anaphases, and micronuclei in telophases and tetrads, were recorded in high frequency in all the accessions generating unbalanced gametes. Both accessions of B. bovonei presented chromosome stickiness. The results are discussed in the view of the Brachiaria breeding program objectives.

Key words: Brachiaria, meiosis, chromosome number, polyploidy, breeding program
\end{abstract}

\section{MICROSPOROGÊNESE EM BRACHIARIA BOVONEI (CHIOV.) ROBYNS E B. SUBULIFOLIA (MEZ) CLAYTON (POACEAE)}

\begin{abstract}
RESUMO: Algumas espécies africanas de Brachiaria foram introduzidas nas Américas e tornaram-se importantes pastagens nos trópicos. Novas cultivares podem ser obtidas por seleção direta da variabilidade genética existente na coleção de germoplasma ou por hibridização interespecífica. Poliploidia é predominante no gênero Brachiaria e correlacionada com apomixia, o que complica a hibridização. O objetivo dos estudos citogenéticos na coleção de germoplasma de Brachiaria da Embrapa Gado de Corte é determinar o número de cromossomos e o comportamento meiótico dos acessos. A microsporogênese foi avaliada em dois acessos de Brachiaria bovonei (BO01 e BO05) e um acesso de B. subulifolia (SU01). BO01 é pentaplóide $(2 \mathrm{n}=5 \mathrm{x}=45)$, BO05 é tetraplóide $(2 \mathrm{n}=4 \mathrm{x}=$ 36), e SU01 é hexaplóide ( $2 n=6 x=54)$, todos derivados de $x=9$. Anormalidades meióticas típicas de poliplóides, caracterizadas por migração precoce de cromossomos para os pólos em metáfases, cromossomos retardatários em anáfases, e micronúcleos em telófases e tétrades foram observadas em alta freqüência em todos os acessos gerando gametas geneticamente desbalanceados. Ambos os acessos de $B$. bovonei apresentaram aderências cromossômicas. Os resultados são discutidos sob o ponto de vista dos objetivos do melhoramento genético.

Palavras-chave: Brachiaria, meiose, número de cromossomos, poliploidia, melhoramento
\end{abstract}

\section{INTRODUCTION}

The main germplasm collections of Brachiaria in the world are in Colombia (International Center for Tropical Agriculture - CIAT) with 687 accessions, Ethiopia (International Livestock Center for Africa -
ILCA) with 520 accessions, and Brazil (Embrapa Beef Cattle Research Center - CNPGC) with 475 accessions. Some species, however, are poorly represented in these centers. Nine accessions of $B$. bovonei (Chiov.) Robyns and nine of $B$. subulifolia (Mez) Clayton are found in the three main germplasm col- 
lections above cited (Keller-Grein et al., 1996). At CNPGC, only two accessions of $B$. bovonei and one accession of $B$. subulifolia are actually available. According to Renvoize's taxonomic classification (Renvoize et al., 1996) B. bovonei and B. subulifolia belong to group 6 based on morphological descriptors. The first presents rachis almost triquetrous while the second presents upper lemma nipped at the tip. Both species are of African origin.

The majority of Brachiaria species is polyploid (Basappa et al., 1987; Valle \& Savidan, 1996; MendesBonato et al., 2002, 2006; Utsunomiya et al., 2005; Risso-Pascotto et al., 2006a). The analysis of DNA content by flow cytometry indicated that polyploidy in the CNPGC collection ranged from $4 \mathrm{n}$ to $7 \mathrm{n}$ (Penteado et al., 2000). The tetraploid level largely predominates in this collection (58\%). Some species, such as $B$. bovonei, were not evaluated by flow cytometry, but among those analyzed, including $B$. subulifolia, the authors recommended a confirmation of ploidy level by chromosome counting. Thus, besides determining the chromosome number in both species, this study also presents data about their meiotic behavior as a contribution to the Brachiaria breeding program.

\section{MATERIALAND METHODS}

Two accessions of $B$. bovonei (BO01 and BO05) and one accession of B. subulifolia (SU01) available at Embrapa Beef Cattle Research Center (Campo Grande, MS, Brazil) were evaluated. Both accessions were collected in wild East African savannas in the 1980s by the International Center for Tropical Agriculture (CIAT, Colombia), and then, transferred to Embrapa Genetic Resources and Biotechnology Center - Cenargen (Brazil). After quarantine they were transferred to Campo Grande where they are kept in plots in the field. The site characteristics of cultivation in Campo Grande, Mato Grosso do Sul, Brazil are: climate type Aw: tropical humid savanna; average annual precipitation $=1,526 \mathrm{~mm}$; average temperature = $22^{\circ} \mathrm{C}$; altitude $520 \mathrm{~m}$; $20^{\circ} 28^{\prime} \mathrm{S}$; $55^{\circ} 40^{\prime} \mathrm{W}$; Oxisol (590 $\mathrm{g} \mathrm{kg}^{-1}$ sand; $80 \mathrm{~g} \mathrm{~kg}^{-1}$ silt; $330 \mathrm{~g} \mathrm{~kg}^{-1}$ clay; $\mathrm{pH}=$ $4.2)$.

Inflorescences for meiotic study were collected in 16 clonal plants representing each accession and fixed in a mixture of $95 \%$ ethanol, chloroform and propionic acid (6:3:2) for 24 hours, transferred to $70 \%$ alcohol and stored under refrigeration until use. Microsporocytes were prepared by squashing and staining with $0.5 \%$ propionic carmine. Photomicrographs were taken in a Wild Leitz microscope using Kodak Imagelink - HQ, ISO 25 black and white film.

\section{RESULTS}

Chromosome counting of both species at diakinesis and anaphase I revealed that BO01 accession is pentaploid $(2 n=5 x=45)$ (Figure 1a), BO05 is tetraploid $(2 \mathrm{n}=4 \mathrm{x}=36)$ (Figure 2a), and SU01 is hexaploid $(2 n=6 x=54)$, derived from $x=9$. The meiotic behavior of these accessions was evaluated and several meiotic abnormalities were recorded (Table 1). The most common abnormalities in the three accessions were those related to irregular chromosome segregation due to polyploidy (Figure 1 and Figure 2). In the pentaploid accession of $B$. bovonei (BO01) (Figure $1 \mathrm{~b}$ ) and in the hexaploid accession SU01, several multivalent chromosomes associations were observed. However, in the tetraploid accession of $B$. bovonei (BO05) chromosomes associated predominantly as bivalents, and few quadrivalents were recorded at diakinesis (Figure 2a). Precocious chromosome migration to the pole in metaphase I (Figure 1c), and metaphase II (Figure 1g and Figure 2e), laggards in anaphase I (Figure 1f, g and Figure 2b, c) and anaphase II (Figure $1 \mathrm{~h}$ and Figure 2f), leading to micronuclei formation in telophase I (Figure 1e and Figure 2d) and telophase II (Figure 1 i and Figure 2 g) were recorded in high frequency in the three accessions. The meiotic fate of telophase I and II micronuclei varied among accessions. In BO01, some micronuclei of telophase I were eliminated as microcytes at the end of the first division in $50 \%$ of meiocytes (Figure $1 \mathrm{f}$ ). The same behavior was found after the second division when micronuclei were eliminated as microcytes in the tetrad (Figure $1 \mathrm{k}, \mathrm{l}$ ). In this accession, however, the majority of micronuclei remained in the tetrad (Figure 1j, k, l). In BO05, micronuclei remained inside the microspores in all the tetrads (Figure 2h, i). Micronuclei and microcytes in tetrads were also observed in SU01. Chromosome stickiness was another meiotic abnormality detected in both accessions of $B$. bovonei.

\section{DISCUSSION}

Two basic chromosome numbers have been reported along decades for several species in the genus Brachiaria, $\mathrm{x}=7$ and $\mathrm{x}=9$ (Basappa et al., 1987; Bernini \& Marin-Morales, 2001; Valle \& Savidan, 1996; Mendes-Bonato et al., 2002, 2006; Utsunomiya et al., 2005). However, recently, a new basic chromosome number, $\mathrm{x}=6$, was reported for $B$. dictyoneura (Risso-Pascotto et al., 2006b). There is a wide prevalence of polyploid forms in the genus Brachiaria, with a predominance of tetraploid accessions within species (Mendes-Bonato et al., 2002, 2006; Utsunomiya 
Table 1 - Meiotic abnormalities in Brachiaria bovonei and B. subulifolia.

\begin{tabular}{|c|c|c|c|c|c|c|c|}
\hline \multirow[t]{2}{*}{ Phases } & \multirow[t]{2}{*}{ Abnormalities } & \multicolumn{2}{|c|}{$\begin{array}{c}\text { BO01 } \\
2 n=5 x=45\end{array}$} & \multicolumn{2}{|c|}{$\begin{array}{c}\mathrm{BO} 05 \\
2 \mathrm{n}=4 \mathrm{x}=36\end{array}$} & \multicolumn{2}{|c|}{$\begin{array}{c}\text { SU01 } \\
2 n=6 x=54\end{array}$} \\
\hline & & $\begin{array}{c}\text { No. of } \\
\text { PMCs } \\
\text { analyzed }\end{array}$ & $\begin{array}{c}\text { No. of } \\
\text { abnormal } \\
\text { PMCs }\end{array}$ & $\begin{array}{c}\text { No. of } \\
\text { PMCs } \\
\text { analyzed }\end{array}$ & $\begin{array}{c}\text { No. of } \\
\text { abnormal } \\
\text { PMCs }\end{array}$ & $\begin{array}{c}\text { No. of } \\
\text { PMCs } \\
\text { analyzed }\end{array}$ & $\begin{array}{c}\text { No. of } \\
\text { abnormal } \\
\text { PMCs }\end{array}$ \\
\hline \multirow[t]{2}{*}{ Metaphase I } & $\begin{array}{l}\text { Precocious chromosome } \\
\text { migration }\end{array}$ & 210 & 108 & 126 & 25 & 150 & 60 \\
\hline & Chromosome stickiness & & 17 & & 19 & & - \\
\hline \multirow[t]{2}{*}{ Anaphase I } & Laggard chromosomes & 127 & 79 & 112 & 31 & 136 & 108 \\
\hline & Chromosome stickiness & & 2 & & 8 & & - \\
\hline \multirow[t]{2}{*}{ Telophase I } & Micronuclei & 164 & 48 & 152 & 12 & 140 & 86 \\
\hline & Chromosome stickiness & & 9 & & - & & 14 \\
\hline \multirow[t]{3}{*}{ Prophase II } & Micronuclei & 198 & 97 & 113 & 61 & 125 & 61 \\
\hline & Chromosome stickiness & & 29 & & - & & - \\
\hline & Microcytes & & 17 & & - & & - \\
\hline \multirow[t]{3}{*}{$\begin{array}{l}\text { Metaphase } \\
\text { II }\end{array}$} & $\begin{array}{l}\text { Precocious chromosome } \\
\text { migration }\end{array}$ & 216 & 46 & 134 & 56 & 155 & 102 \\
\hline & Chromosome stickiness & & 19 & & 3 & & - \\
\hline & Microcytes & & 23 & & - & & - \\
\hline \multirow[t]{3}{*}{ Anaphase II } & Laggard chromosomes & 157 & 122 & 99 & 41 & 120 & 96 \\
\hline & Chromosome stickiness & & 13 & & 4 & & - \\
\hline & Microcytes & & 9 & & - & & - \\
\hline \multirow[t]{2}{*}{ Telophase II } & Micronuclei & 233 & 176 & 172 & 94 & 134 & 109 \\
\hline & Microcytes & & 35 & & - & & - \\
\hline \multirow[t]{3}{*}{ Tetrad } & Micronuclei & 160 & 136 & 87 & 58 & 159 & 130 \\
\hline & Microcytes & & 11 & & - & & - \\
\hline & $\begin{array}{l}\text { Micronuclei and } \\
\text { microcytes }\end{array}$ & & 21 & & - & & - \\
\hline Total & & 1465 & $\begin{array}{c}1017 \\
(69.42 \%)\end{array}$ & 995 & $\begin{array}{c}412 \\
(41.42 \%)\end{array}$ & 1119 & $\begin{array}{c}766 \\
(68.45 \%)\end{array}$ \\
\hline
\end{tabular}

et al., 2005; Risso-Pascotto et al., 2006a). Among several species studied, only a few hexaploid accessions $(2 \mathrm{n}=6 \mathrm{x}=54)$ were recorded and only in B. brizantha (Mendes-Bonato et al., 2002).

The abnormalities observed in the accessions under analysis were recorded in other polyploid accessions of different species of Brachiaria (MendesBonato et al., 2002, 2006; Utsunomiya et al., 2005; Risso-Pascotto et al., 2006a). The meiotic fate of micronuclei in the genus Brachiaria seems to be genotype-specific. Accessions of different species and within species behaved differently in relation to micronuclei fate (Mendes-Bonato et al., 2002, 2006; Utsunomiya et al., 2005; Risso-Pascotto et al., 2006 a), but unbalanced gametes are formed either way.

Chromosome stickiness observed in $B$. bovonei has been frequently reported in different species of the genus Brachiaria (Mendes-Bonato et al., 2001a, b; Utsunomiya et al., 2005; Risso-Pascotto et al., 2005). Chromosome stickiness is characterized by intense chromosome clustering during any phase of the cell cycle. Chromosomes start to assemble at prophase I or metaphase I, frequently form congregations and do not orientate correctly on the equatorial plate. They display failure or irregular anaphase I disjunction, while chromosome fragmentation occurs from prophase I onwards, resulting in male and female sterility (Rao et al., 1990) Although chromosome stickiness is a cytological phenomenon that has been recorded for almost a century, adequate explanations are still lacking.

The abnormalities related to irregular chromosome segregation recorded in these accessions are typical of polyploids. However, the frequency could be affected by environmental factors. In Brachiaria, the environmental effect in the meiotic process was demonstrated in an interspecific hybrid between $B$. ruziziensis and $B$. brizantha cultivated in three distinct years (Fuzinatto et al., 2008). Several meiotic abnormalities were recorded and varied in type and frequency in the three years of collection. Studies developed in many 


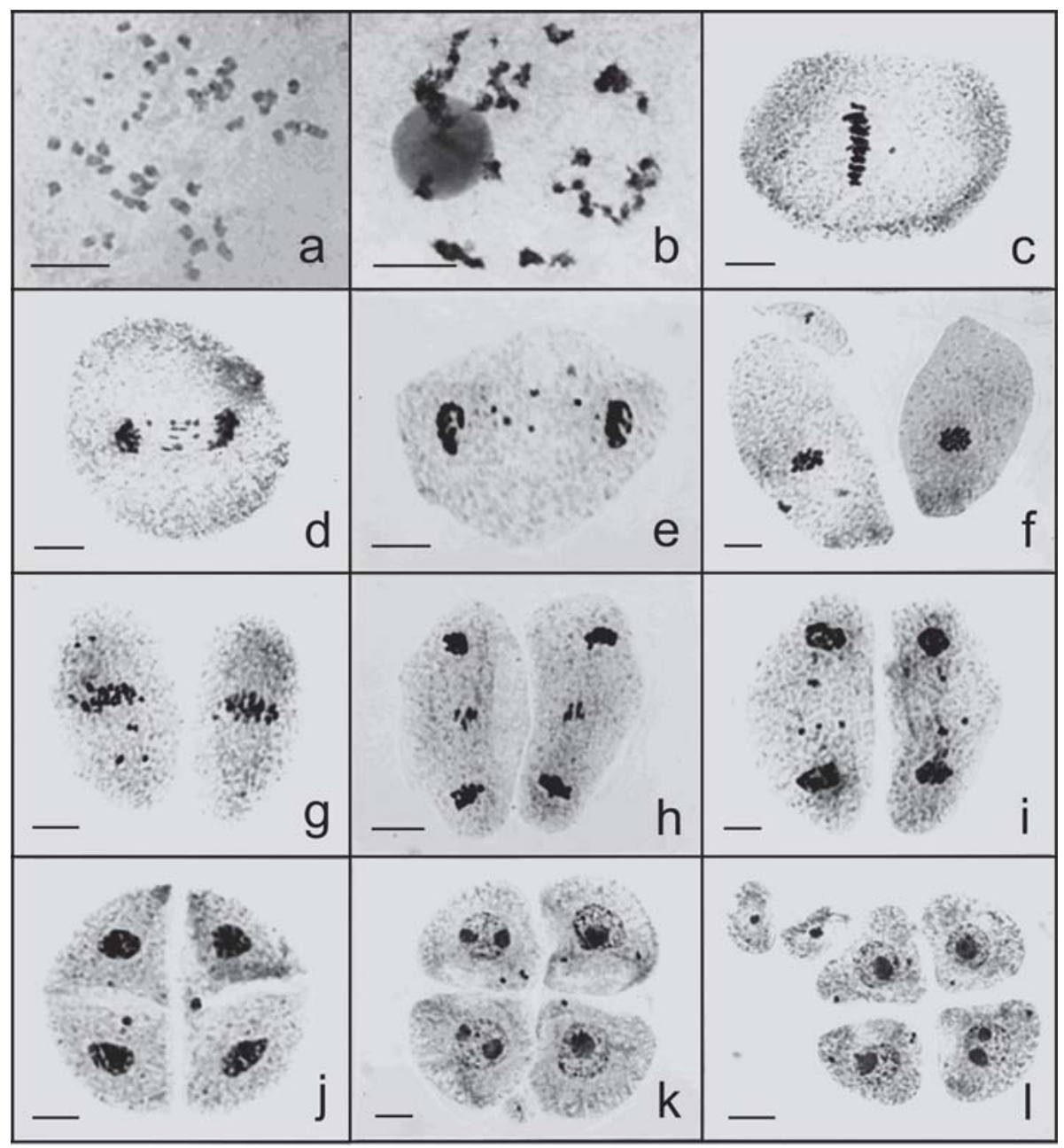

Figure 1 - Aspects of microsporogenesis in BO01 $(2 n=5 x=45)$. a) Anaphase I showing 45 segregated chromosomes. b) Diakinesis with several multivalents. c) Metaphase I with precocious chromosome migration to the poles. d) Anaphase I with laggards. e) Telophase I with micronuclei. f) Metaphase II with a micronuclei and a microcyte. g) Metaphase II with precocious chromosome migration to the poles. h) Anaphase II with laggards. i) Telophase II with micronuclei. j) Tetrad with micronuclei in two microspores. k, l) Tetrads with micronuclei and microcytes. Scale bars $=19 \mu \mathrm{m}$.

species of higher plants revealed that the reproductive processes appear to be much more sensitive to abiotic stresses than vegetative growth (Sato et al., 2002). Meiosis is the most sensitive stage in the life cycle of seed plants (Saini, 1997; Porch \& Jahn, 2001; Erickson \& Markhart, 2002). Among the abiotic stresses capable of inducing abnormalities during meiosis, Sun et al. (2004) cited water availability, temperature, nutrient levels, light, soil salinity, and pollution.

In Brachiaria and several others forage grass, polyploidy is closely associated with asexual reproduction - apomixis. Studies on the reproductive biology of the Brachiaria germplasm collection at Embrapa Beef Cattle revealed that the accessions under analysis are apomictic (Valle \& Savidan, 1996). Polyploidy, in general, disturbs meiotic process leading to unviable gamete formation. In the absence of gametes, reproduction is asexual. However, in Brachiaria, apomixis is pseudogamic (Valle \& Savidan, 1996), that means that viable male gametes are necessary to fertilize the secondary nucleus of embryo sac to develop the endosperm of the seed. Seed set was not yet evaluated in the present accessions.

The objective of cytological studies underway on the Brachiaria germplasm collection at Embrapa Beef Cattle is to determine the chromosome number of accessions, mode of reproduction, and meiotic behavior. For the breeding of Brachiaria species, compatible sexual and apomictic accessions need to be identified. Interploid crosses were attempted without success (Ferguson \& Crowder, 1974; Hacker, 1988) but once ploidy barriers were removed, several interesting hybrids were produced. Hybridization is being done among some rare sexual tetraploid accessions, mainly of $B$. ruziziensis artificially tetraploidized by colchicine in Belgium (Swenne et al., 1981; Gobbe et al., 1981) and more recently of a 


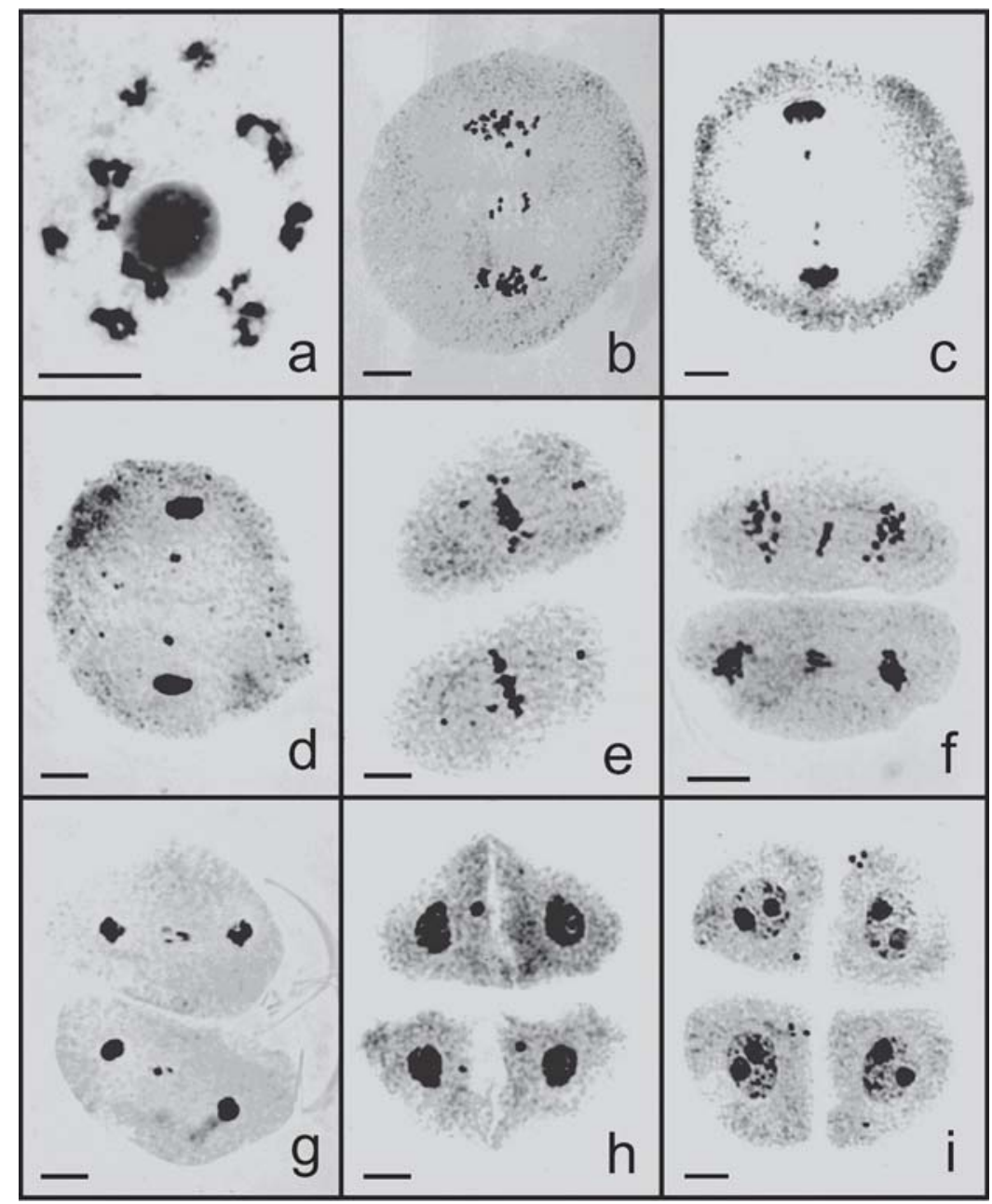

Figure 2 - Aspects of microsporogenesis in BO05 $(2 n=4 x=36)$. a) Diakinesis with 16 bivalents and one quadrivalent. b, c) Anaphase I with several laggards. d) Telophase I with micronuclei. e) Metaphase II with precocious chromosome migration to the poles. f) Anaphase II with laggards. g) Telophase II with micronuclei. h) Tetrad with micronuclei in three microspores. i) Tetrads with micronuclei in the four microspores. Scale bars $=19 \mu \mathrm{m}$.

natural tetraploid sexual $B$. humidicola, with apomictic tetraploid accessions as pollen donors. For an apomictic tetraploid accession to act as a male genitor, meiotic stability is required to guarantee endosperm development and to produce normal tetraploid hybrid progeny, with both sexual and apomictic reproduction. From the cytogenetic data obtained in the present analysis, none of the three accessions analyzed could be recommended for interspecific hybridization because of high meiotic instability (BO01 $=69.42 \%$, BO05 $=41.42 \%$, and SU01 $=68.45 \%$ ) and also because of the ploidy level detected in BO01 (5x) and SU01 (6x). Phylogenetic studies also need to be carried out with these species to determine compatibility with agronomic important species. Cytogenetic studies need to continue in the germplasm Brachiaria collection to find ideal accessions for the breeding program, either for intraspecific or interspecific hybridization.

\section{ACKNOWLEDGMENTS}

Authors are grateful to UNIPASTO for financial support.

\section{REFERENCES}

BASAPPA, G.P.; MUNIYAMMA, M.; CHINNAPPA, C.C. An investigation of chromosome numbers in the genus Brachiaria (Poaceae: Paniceae) in relation to morphology and taxonomy. Canadian Journal of Botany, v.65, p.22972309, 1987.

BERNINI, C.; MARIN-MORALES, M.A. Karyotype analysis in Brachiaria (Poaceae) species. Cytobios, v.104, p.57-171, 2001.

ERICKSON, A.N.; MARKHART, A.H. Flower development stage and organ sensitivity of bell pepper (Capsicum annuum L.) to elevated temperature. Plant Cell Environment, v.25, p.123$130,2002$.

FERGUSON, J.E.; CROWDER, L.V. Cytology and breeding behavior of Brachiaria ruziziensis Germain et Evrard. Crop Science, v.14, p.893-895, 1974. 
FUZINATTO, V.A.; PAGLIARINI, M.S.; VALLE, C.B. Evaluation of microsporogenesis in an interspecific Brachiaria hybrid (Poaceae) collected in distint years. Genetics and Molecular Research, v.7, p.424-432, 2008.

GOBBE, J.; SWENNE, A.; LOUANT, B.P. Diploïdes naturels et autotétraploïdes induits chez Brachiaria ruziziensis Germain et Evrard: critères d'identification. Agronomia Tropical, v.36, p.339-346, 1981.

HACKER, J.B. Sexuality and hybridization in signalgrass, Brachiaria decumbens. Tropical Grasslands, v.22, p.139-144, 1988.

KELLER-GREIN, G.; MAASS, B.L.; HANSON, J. Natural variation in Brachiaria and existing germoplasma collections. In: MILES, J.W.; MAASS, B.L.; VALLE, C.B. (Ed) Brachiaria: biology, agronomy, and improvement. Campo Grande: Embrapa, 1996. p.17-42.

MENDES-BONATO, A.B.; PAGLIARINI, M.S.; FORLI, F.; VALLE, C.B.; PENTEADO, M.I.O. Chromosome number and microsporogenesis in Brachiaria brizantha (Gramineae). Euphytica, v.125, p.419-425, 2002.

MENDES-BONATO, A.B.; PAGLIARINI, M.S.; RISSOPASCOTTO, C.; VALLE, C.B. Chromosome number and meiotic behavior in Brachiaria jubata (Gramineae). Journal of Genetics, v.85, p.83-87, 2006.

MENDES-BONATO, A.B.; PAGLIARINI, M.S.; VALLE, C.B.; PENTEADO, M.I.O. A severe case of chromosome stickiness in pollen mother cells of Brachiaria brizantha (Hochst) Stapf (Gramineae). Cytologia, v.66, p.287-291, 2001a.

MENDES-BONATO, A.B.; PAGLIARINI, M.S.; VALLE, C.B.; PENTEADO, M.I.O. Meiotic instability in invader plants of signal grass Brachiaria decumbens Stapf (Gramineae). Acta Scientiarum, v.23, p.619-625, 2001 b.

PENTEADO, M.I.O.; SANTOS, A.C.M.; RODRIGUES, I.F.; VALLE, C.B.; SEIXAS, M.A.C.; ESTEVES, A. Determinação de poliploidia e avaliação da quantidade de DNA total em diferentes espécies de gênero Brachiaria. Campo Grande: Embrapa Gado de Corte, 2000. 19p. (Boletim de Pesquisa, 11).

PORCH, T.G.; JAHN, M. Effects of high-temperature stress on microsporogenesis in heat-sensitive and heat-tolerant genotypes of Phaseolus vulgaris. Plant Cell Environment, v.24, p.723731, 2001.

RAO, P.N.; KANGANADHAAM, P.; NIRMALA, A. Behavior of a sticky desynaptic mutant in pearl millet. Genetica, v.81, p.221227, 1990
RENVOIZE, S.A.; CLAYTON, W.D.; KABUYE, C.H.S. Morphology, taxonomy, and natural distribution of Brachiaria (Trin.) Griseb. In: MILES, J.W.; MAASS, B.L.; VALLE, C.B. (Ed) Brachiaria: biology, agronomy, and improvement. Campo Grande: Embrapa, 1996. p.1-15.

RISSO-PASCOTTO, C.; PAGLIARINI, M.S.; VALLE, C.B. A new basic chromosome number for the genus Brachiaria (Trin.) Griseb. (Poaceae: Panicoideae: Paniceae). Genetic Resources and Crop Evolution, v.53, p.7-10, 2006b.

RISSO-PASCOTTO, C.; PAGLIARINI, M.S.; VALLE, C.B. Meiotic behavior in interspecific hybrids between Brachiaria ruzizensis and Brachiaria brizantha (Poaceae). Euphytica, v.145, p.155159, 2005.

RISSO-PASCOTTO, C.; PAGLIARINI, M.S.; VALLE, C.B. Microsporogenesis in Brachiaria dictyoneura (Fig. \& De Not.) Stapf (Poaceae: Paniceae). Genetics and Molecular Research, v.5, p.837-845, 2006a.

SAINI, H.S. Effects of water stress on male gametophyte development in plants. Sexual Plant Reproduction, v.10, p.67-73, 1997.

SATO, S.; PEET, M.M.A.; THOMAS, J.F. Determining critical pre- and post-anthesis periods and physiological processes in Lycopersicum esculentum Mill. exposed to moderately elevated temperature. Journal of Experimental Botany, v.53, p.11871195, 2002

SUN, K.; HUNT, K.; HAUSER, B.A. Ovule abortion in Arabidopsis triggered by stress. Plant Physiology, v.135, p.2358-2367, 2004.

SWENNE, A.; LOUANT, B.P.; DUJARDIN, M. Induction par la colchicines de formes autotétraploïdes chez Brachiaria ruziziensis Germain et Evrard (Gramínée). Agronomia Tropical, v.36, p.134-141, 1981.

UTSUNOMIYA, K.S.; PAGLIARINI, M.S.; VALLE, C.B. Microsporogenesis in tetraploid accessions of Brachiaria nigropedata (Ficalho \& Hiern) Stapf (Gramineae). Biocell, v.29, p.295-301, 2005.

VALLE, C.B.; SAVIDAN, Y. Genetics, cytogenetics, and reproductive biology of Brachiaria. In: MILES, J.W.; MAASS, B.L.; VALLE, C.B. (Ed) Brachiaria: biology, agronomy, and improvement. Campo Grande: Embrapa, 1996. p.147-163.

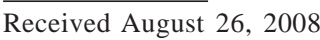

Accepted April 17, 2009 